\title{
Forests and Public Policies in the Argentine Northern Patagonia Region-Small Producers, Capitals, and Territorial Claims
}

\author{
Valeria Iñigo Carrera, Alejandro Balazote, and Gabriel Stecher
}

\begin{abstract}
The mountainous area in the provinces of Neuquén and Río Negro (Argentine Northern Patagonia) is extremely rich in terms of native forest cover, soils, grasslands, waters, and landscapes. Consequently, the area is highly valued for tourism and its associated activities (real estate, for example), among others. The increase of national and foreign capitals applied to these activities entails a threat for the traditional dwellers of these lands and territories: small producers who identify themselves as belonging to indigenous peoples, and those with a criollo origin. In 2007, National Law No. 26,331 on "Minimum Standards for the Environmental Protection of Native Forests" was enacted, as well as Provincial Laws No. 2,780 and No. 4,552 in Neuquén and Río Negro provinces, respectively. From then on, the management of forest areas has been subject to regulation by both the federal and the provincial states. This chapter examines the implications of public policies regarding nature conservation — in general — and territorial planning of native forests - in particular - in relation to the territorialities configured by the different social subjects. Furthermore, it analyzes the dynamics of increasing territorial conflicts in the forested areas of the mountain region in both provinces, as a result of the advance of different public and private ventures on lands and territories occupied by the above-mentioned small producers.
\end{abstract}

Keywords Forests · Regulations - Territories · Policies

V. Iñigo Carrera $(\square)$

Universidad Nacional de Río Negro (UNRN) - Consejo Nacional de Investigaciones

Científicas y Técnicas (CONICET), Instituto de Investigaciones en Diversidad Cultural y

Procesos de Cambio (IIDyPCa), San Carlos de Bariloche, Argentina

A. Balazote

Universidad de Buenos Aires (UBA), Buenos Aires, Argentina

A. Balazote

Universidad Nacional de Luján (UNLu), Luján, Argentina

G. Stecher

Universidad Nacional del Comahue (UNComa), Asentamiento Universitario San Martín de

Los Andes, Cátedra Extensión Rural, San Martín de los Andes, Argentina

(C) The Author(s), under exclusive license to Springer Nature Switzerland AG 2021

C. M. Minaverry and S. Valverde (eds.), Ecosystem and Cultural Services, The Latin

American Studies Book Series, https://doi.org/10.1007/978-3-030-78378-5_6 


\section{Introduction}

Since November 2007, the surface of native forests in Argentina has been managed by the State - at its different levels - pursuant to the established criteria for its enrichment, restoration, conservation, use and sustainable management, as well as those of the environmental services they provide to society, based on the provisions of National Law No. 26,331 on "Minimum Standards for the Environmental Protection of Native Forests" (known as the "Forest Law"). ${ }^{1}$ A proportion of this surface, corresponding to the northwestern region of the Andean-Patagonian forests, is located in the mountain area of the provinces of Neuquén and Río Negro (Argentine Northern Patagonia) (Fig. 1) $)^{2}$ These lands are extremely rich, not only in terms of native forest mass but also soils, grasslands, waters, and landscapes. The traditional dwellers of these lands and territories are small producers who belong to - or who identify themselves as belonging to-indigenous peoples (in particular, the Mapuche people), ${ }^{3}$ as well as those with a criollo origin. ${ }^{4}$ National and foreign capitals have recently appropriated these lands and territories, particularly by means of consolidating the region for tourism and real estate expansion purposes (Blanco and Arias 2018; Iñigo Carrera 2019; Trpin and Rodríguez 2019; Valverde et al. 2015).

\footnotetext{
${ }^{1}$ Current legislation considers native forests as natural forest ecosystems mainly consisting of mature native tree species, with various species of associated flora and fauna, together with the environment that surrounds them (Art. 2, National Law No. 26,331). The tangible and intangible benefits generated by the native forest ecosystems are considered to be environmental services, namely water regulation; the conservation of biodiversity, soil and water quality; fixing of greenhouse gas emissions; the contribution to landscape diversification and beauty; the defense of cultural identity (Art. 5, National Law No. 26,331).

${ }^{2}$ Patagonia is located in the southern tip of Latin America, comprising the southern territories of Chile and Argentina. In Argentina, it covers part of the provinces of Buenos Aires, La Pampa and Mendoza, and the whole of the provinces of Neuquén, Río Negro, Chubut, Santa Cruz and Tierra del Fuego, Antarctica, and the South Atlantic Islands. This work focuses on the Northern Patagonian districts, mainly Neuquén and Río Negro. The Argentine Northern Patagonia region includes two types of subregions with differentiated geomorphological, climate, hydric, and vegetation features: the one located along the Andes mountain range, with the Andean-Patagonian forest on its slopes; and the other one with highlands and wide plateaus, where the Patagonian steppe is located.

${ }^{3}$ The Mapuche are one of the indigenous peoples that existed before the creation of the Argentine nation-state, a process based on the violent incorporation of those peoples. There are numerous academic of papers that conceptualize the expansive process of the national State and the policy applied to the indigenous peoples during the military conquest years (late nineteenth century) as a genocide (Delrio et al. 2010; Tamagno 2014; Trinchero 2006). A shift in the main production relations ensued, and the Mapuche inhabitants reproduced a precarious situation of land tenure which, to a great extent, remains unchanged until today, although they are increasingly organized in communities, Lof (collective subject based on family and land relations) and organizations based on claiming their specific ethnic identity and demanding the fulfillment of their acknowledged rights.

${ }^{4}$ Criollos are local, non-indigenous, residents of mainly European ancestry. They make up peasants communities.
} 
Fig. 1 Native forests under the "Forest Law" in Neuquén and Río Negro, Argentina. Source Map made by the authors, based on data from the National Monitoring System of Native Forests of the Argentine Republic. Free software QGIS 3.12

Bucurestti. Author Gabriel Stecher

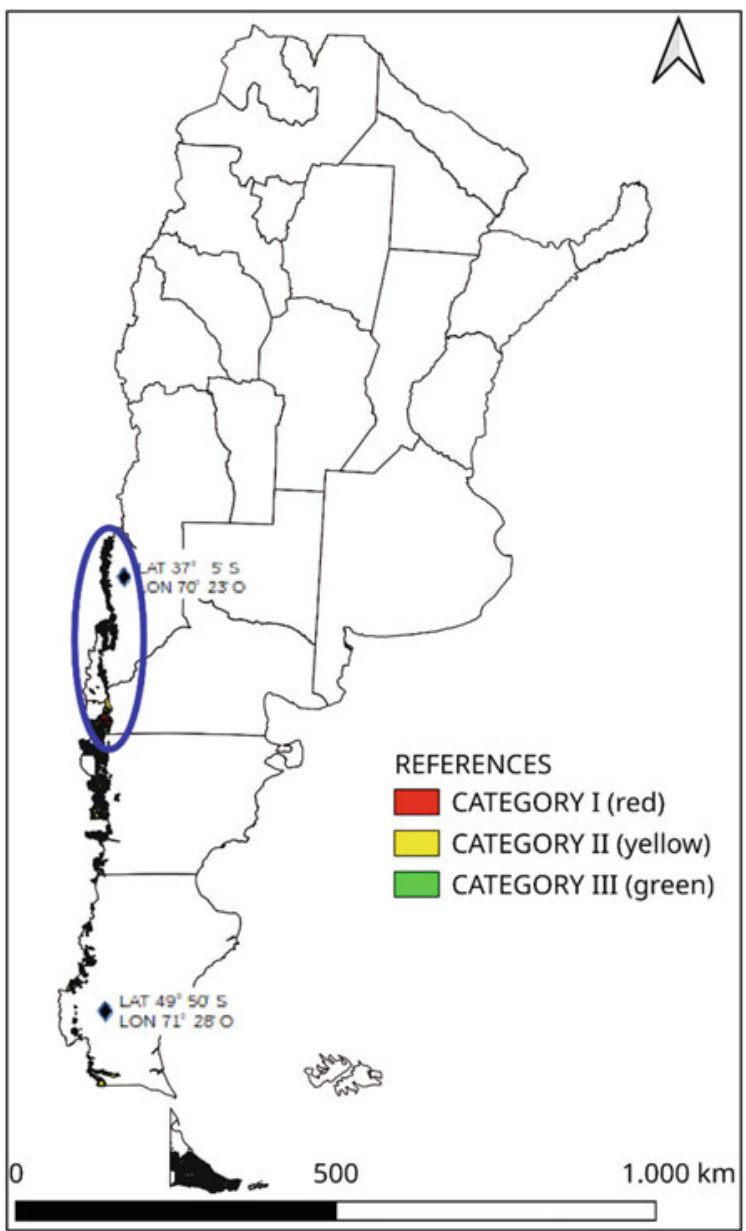

Our work examines the implications of public policies regarding nature conservation - in general - and territorial planning of native forests - in particular - in relation to the territorialities configured by the different social subjects. Furthermore, it analyzes the dynamics of increasing territorial conflicts in the forested areas of the mountain region of Northern Patagonia (in both provinces), as a result of the development of different public and private ventures on lands and territories occupied by small producers, on the one hand, and as a result of the lack of regulation of the producers' ownership of those lands and territories, on the other.

For this purpose, we have structured the chapter as follows. First, we present some general principles of the "Forest Law" and the respective laws by which the provinces of Neuquén and Río Negro abide. Next, we analyze the territorialities configured by the State at its different levels, capitals and small producers 
concerning the territorial planning policy for native forests and the territorial conflicts driven by these different logics, both in the province of Neuquén (Department of Los Lagos) and Río Negro (Department of Bariloche). Finally, we conclude by summarizing our approach. Our work is based on a literature review of empirical studies carried out in the area, analysis of secondary sources, participant-observation experiences, and interviews.

\section{Native Forests: Legislation for Their Territorial Planning in Northern Patagonia}

The surface of native forests in the provinces of Neuquén and Río Negro is managed pursuant to the provisions of National Law No. 26,331. This law was enacted in a context of intensive and extractive exploitation of natural resources, by emerging and multiplying conflicts related to this exploitation led by indigenous peoples and by different local populations (Giarracca 2006; Merlinsky 2013; Seoane 2006), and by the introduction of environmental considerations in public policies (Schmidt 2015). Unlike what happened in the Northern part of the country (in the Yungas area, Misiones rainforest, Espinal and Chaco parks), where deforestation assumed dramatic dimensions in the last two decades, Northern Patagonia was not subject to an equally high rate of deforestation resulting from the expansion of the agricultural frontier (mainly, soybean). Instead, the loss of native forests in Neuquén and Río Negro was one of the lowest in the country and was due to the occurrence of fires. Nevertheless, as the goal of protecting native forests grew to a national level, both provinces had to adhere to the terms set forth by the "Forest Law."

Pursuant to the provisions of National Law No. 26,331, within a maximum period of one year after its enactment, each provincial jurisdiction had to carry out the Territorial Planning of Native Forests (OTBN) in its own territory, following a participatory process and the established sustainability criteria, and configuring the conservation categories based on the environmental value of the different units of native forests and the environmental services provided by them. ${ }^{5}$ The approval of each OTBN by law, and its certification by the National Secretariat of Environment and Sustainable Development (SAyDS), would allow the provinces to access the National Fund for the Enrichment and Conservation of Native Forests, as a compensation to the owners of the affected lands and to the provincial administrations for the conservation of the forests, acknowledging the environmental services they provide.

\footnotetext{
${ }^{5}$ Among the established sustainability criteria, it is worth mentioning criterion No. 10: Value given by the indigenous communities to forested areas and their surroundings, and the use of their natural resources for the purpose of their survival and maintaining their culture. In the "Forest Law," there are various references to the rights vindicated by the indigenous peoples who live or carry out activities in forested areas (Valtriani and Stecher 2019).
} 
Thus, in November 2011, Neuquén passed its Provincial Law No. 2,780 on "Territorial Planning of Native Forests." In July 2010, Río Negro followed suit, passing Provincial Law No. 4,552 on "Conservation and Sustainable Use of Native Forests." In both jurisdictions, the largest amount of native forest surface was included in Category II (yellow-medium conservation value), a lower percentage in Category I (red-high conservation value), and a minimum proportion of that surface was included in Category III (green-low conservation value) (Table 1). ${ }^{6}$

\section{Neuquén: Territorial Planning of Native Forests}

In Neuquén, Provincial Law No. 2,780, passed in 2011, and its subsequent OTBN map, which covers an area of approximately 543,917 ha (Figs. 2 and 3), have sparked much debate since their enactment and provincial enforcement, which included the participation of environmental and social organizations, unions and small producers (indigenous and peasant communities). Following this process, the level of conflict and dispute between the different social subjects involved has increased, as reported by local, regional, and national media (radio, television, and printed or online newspapers).

The State's need to respond to the interests and pressure of dominant groups linked to real estate investments has led to the enactment of regulatory decrees that go against the spirit of the law. Incidentally, they represent a breach of national, provincial, and municipal legislation - which often recovers international declarations and agreements - focused on indigenous and environmental matters, which results in the renewed exclusion and invisibility of the indigenous and peasant communities. Hence, they are denied territorial rights over forested areas of traditional use (Stecher 2013). This situation reproduces a regional development model based on tourism, with a strong extractivist imprint, that widens the social and environmental gaps (Encabo et al. 2016) and considers the landscape and its territorial multi-dimensionalities as a commodity.

Although the legislation provides for the revision and update of this OTBN every five years, the local Enforcement Authority (the Forest Resources Division of the province of Neuquén) has modified the conservation categories, under the figure of "adjustments," even to the extent of excluding areas which were contemplated in the original maps. As we have previously mentioned, these changes are mainly based on real estate development projects, generating strong controversies among the different social subjects. In 2018, the Enforcement Authority opened the participation and consultation instances, as established by law, by holding workshops in the towns located in the mountain area, thus gathering citizens, socio-environmental organizations, and the scientific-technological sector. The

\footnotetext{
${ }^{6}$ It should be noted that they are among the provinces with the lowest area of native forests declared.
} 
Table 1 Total surface of native forest, divided by conservation category, according to the OTBNs of the provinces of Neuquén and Río Negro, in Argentina

\begin{tabular}{l|l|l|l|l|l|l|l|l}
\hline Province & Total surface (Ha) & \multicolumn{2}{l|}{$\begin{array}{l}\text { Surface } \\
\text { category I }\end{array}$} & \multicolumn{2}{l|}{$\begin{array}{l}\text { Surface } \\
\text { category II }\end{array}$} & \multicolumn{2}{l}{$\begin{array}{l}\text { Surface } \\
\text { category III }\end{array}$} \\
\cline { 3 - 9 } & & Ha & $\%$ & Ha & $\%$ & Ha & $\%$ \\
\hline Neuquén & 543,917 & 192,686 & 35 & 347,672 & 64 & 3,559 & 1 \\
\hline Río Negro & 478,900 & 181,900 & 38 & 252,700 & 53 & 44,300 & 9 \\
\hline
\end{tabular}

Source Ministry of Environment and Sustainable Development of Argentina (MAyDS) (2017). Author Gabriel Stecher

Ha: hectares

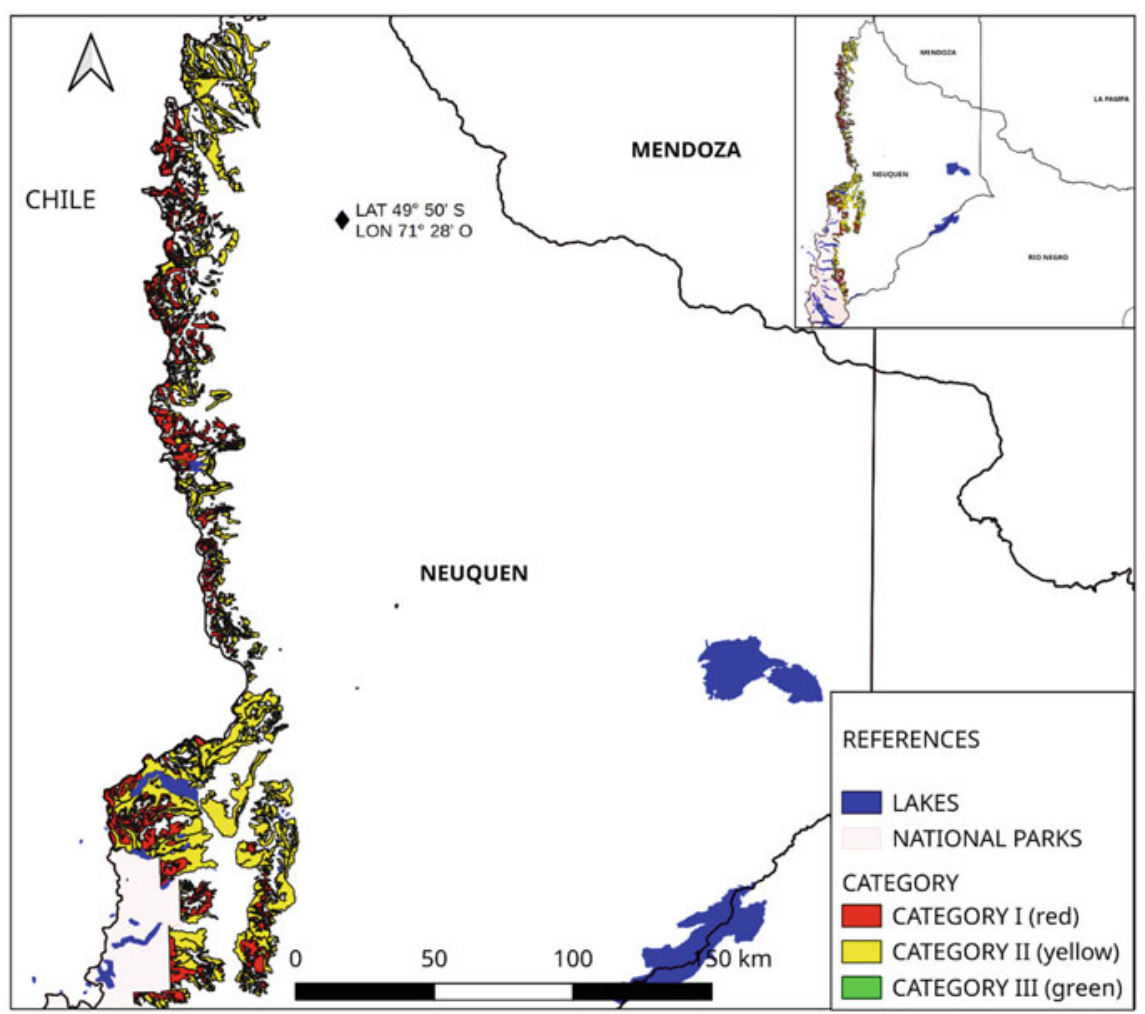

Fig. 2 Territorial Planning of Native Forests (OTBN), province of Neuquén (Northern area), Argentina. Source Map made by the authors, based on data from the National Monitoring System of Native Forests of the Argentine Republic. Free software QGIS 3.12 Bucurestti

methodological proposal was to focus on the representation and construction of new maps, making changes in the conservation categories based on the participants' perspectives, and thus creating spaces to visualize and reveal the different perceptions on which society — both concretely and symbolically—builds its decisions 


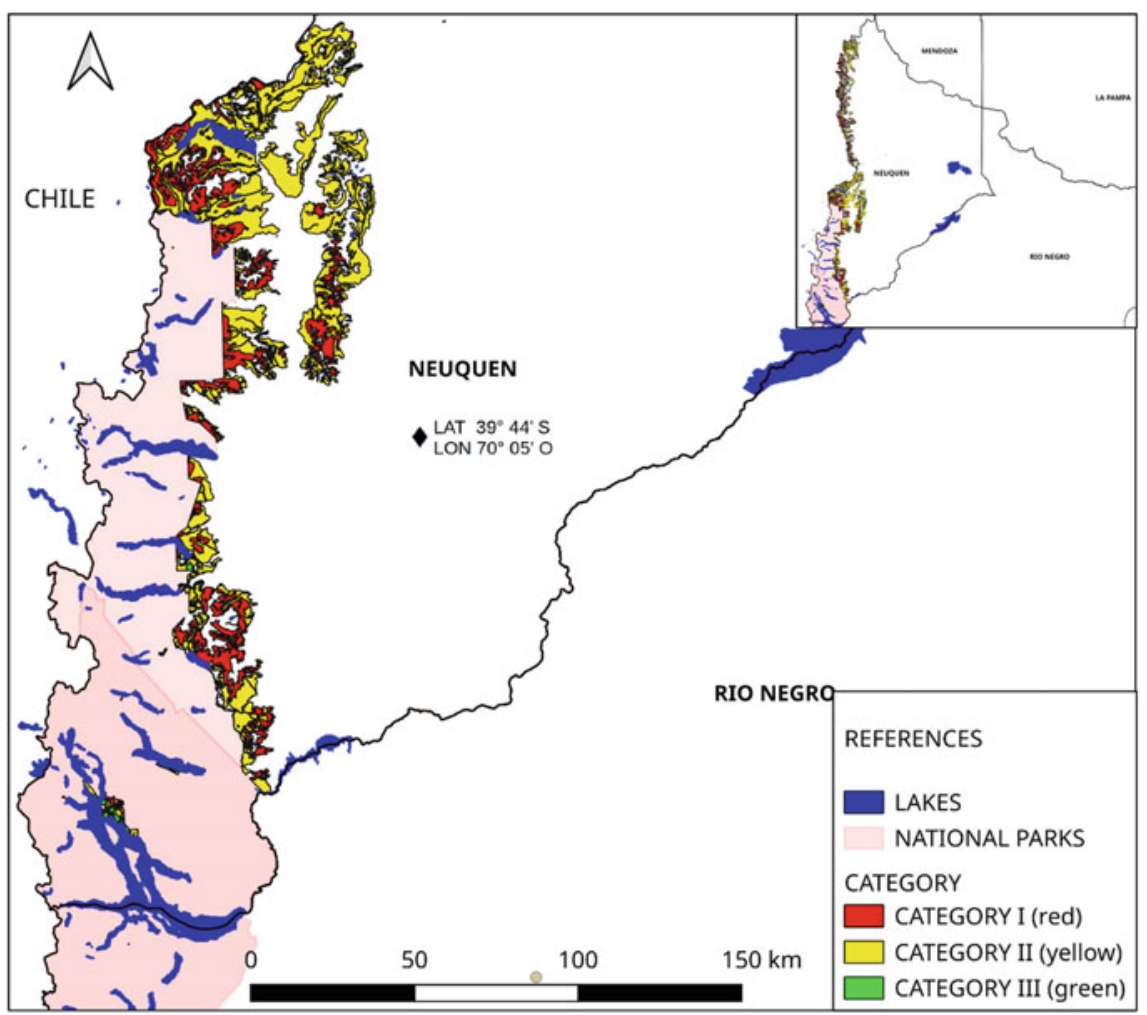

Fig. 3 Territorial Planning of Native Forests (OTBN), province of Neuquén (Southern area), Argentina. Source Map made by the authors, based on data from the National Monitoring System of Native Forests of the Argentine Republic. Free software QGIS 3.12 Bucurestti

about native forests as a common good (Arach and Stecher 2019). Due to the social heterogeneity of those spaces, different positions and analyses emerged-with various levels of agreement-that explicitly revealed the tension about forest conservation in the face of hegemonic development models.

A clear example of what has been described so far, also representative of other situations occurring at the provincial level—as Neuquén is characterized by an important social fabric made of indigenous and peasant communities-is the case of Lof Paichil Antriao. This Mapuche community is located on the slopes of the Belvedere Hill, within the 2-km municipal land surrounding the center of Villa La Angostura (Department of Los Lagos). Over the years, the size of its territory has been considerably reduced, since much of the old Plot 9 (ancestral location) is currently a luxurious residential neighborhood that encompasses important buildings used as households and for tourism purposes.

Since 2003, Lof Paichil Antriao has been conducting a series of mobilizations and judicial claims in search of recognition of its status as part of an indigenous 
group. The provincial government, however, has not acknowledged these claims and much public debate has ensued, regarding indigenous pre-existence in a locality that was always considered as not having any indigenous peoples (García and Valverde 2007). The visibility of these groups has prompted a territorial reconfiguration, transforming the town of Villa La Angostura itself into a contested territory and, as quoted by the aforementioned authors, exacerbating the differences among various government levels, since the Federal State - through the National Parks Administration (APN) and the National Institute of Indigenous Affairs (INAI) - has acknowledged the Mapuche demands. In other words, a process of increasing conflict has started in a contested territory, where different social subjects converge, crossed by deep asymmetries of power (private capitals, the Mapuche community, the State).

In 2017, the Enforcement Authority of the Forest Law authorized opening up a road — of about $1300 \mathrm{~m}$ long, at an average height surpassing the $900 \mathrm{~m}$ benchmark - to have access to a real estate venture ("Correntoso Lake Urbanization and New Waterfront" or "Correntoso Lake Trust") located in the area called Pichunco (Plot 9), in the upper area of the Belvedere Hill. Opening this road implied felling 1.34 ha of forests within a maximum conservation area (Category I) in the OTBN (Figs. 4 and 5).

For its part, if the urbanization of 87 ha surface were fulfilled, it would alter the Correntoso Lake basin, a territory that has traditionally belonged to the Lof Paichil Antriao (Stecher et al. 2018). Although the answer has been to establish an "environmental protection" area, ${ }^{7}$ this action was prosecuted as a crime of unlawful appropriation by the State. However, part of the local society, organized in neighborhood councils, non-governmental organizations, and socio-environmental assemblies, started not only defending the community but also getting involved in the rights guaranteed in the Forest Law (Fig. 6).

On the other hand, the actions based on interpretative intentions, carried out by the Enforcement Authority in favor of real estate stakeholders' groups, created a context of greater social, cultural, and environmental conflict. This not only caused damage to the Lof Paichil Antriao but also created a perception of impunity in other local social groups. Thus, in a clear expression of joint and solidary action within the framework of the participatory instances established by National Law 26,331 to update the OTBN, the social groups managed to keep and even increase the protection categories, against a more lenient new proposal presented by the Enforcement Authority.

\footnotetext{
${ }^{7}$ It should be noted that private plotting will have a serious impact on biodiversity-called ixofijmogen in Mapuche language (Mapuzugun), which translates as "all the lives." Therefore, and considering that "the Mapuche people depends exclusively on it, and we could not develop ourselves as a culture without these various elements that biodiversity offers us, such as lakes, waterfalls, streams, rivers, swamps, menukos (water sources), medicinal plants, native tree species, stones, rocks, land, fauna, biotic species, etc." (Stecher et al. 2018), the plotting will have an equally serious impact on the social life of Lof Paichil Antriao.
} 


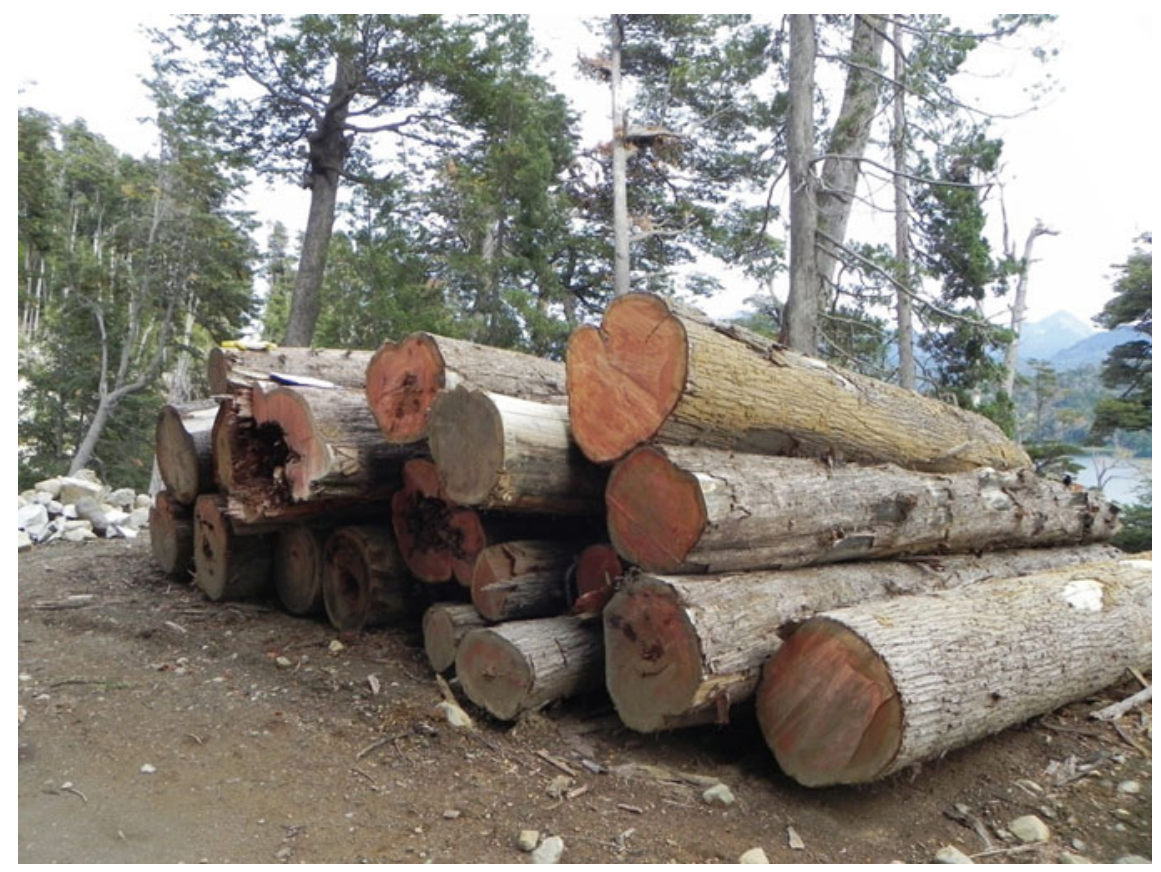

Fig. 4 Deforestation in the area called Pichunco, Villa La Angostura, province of Neuquén, Argentina, 2018. Source Photograph taken by Gabriel Stecher

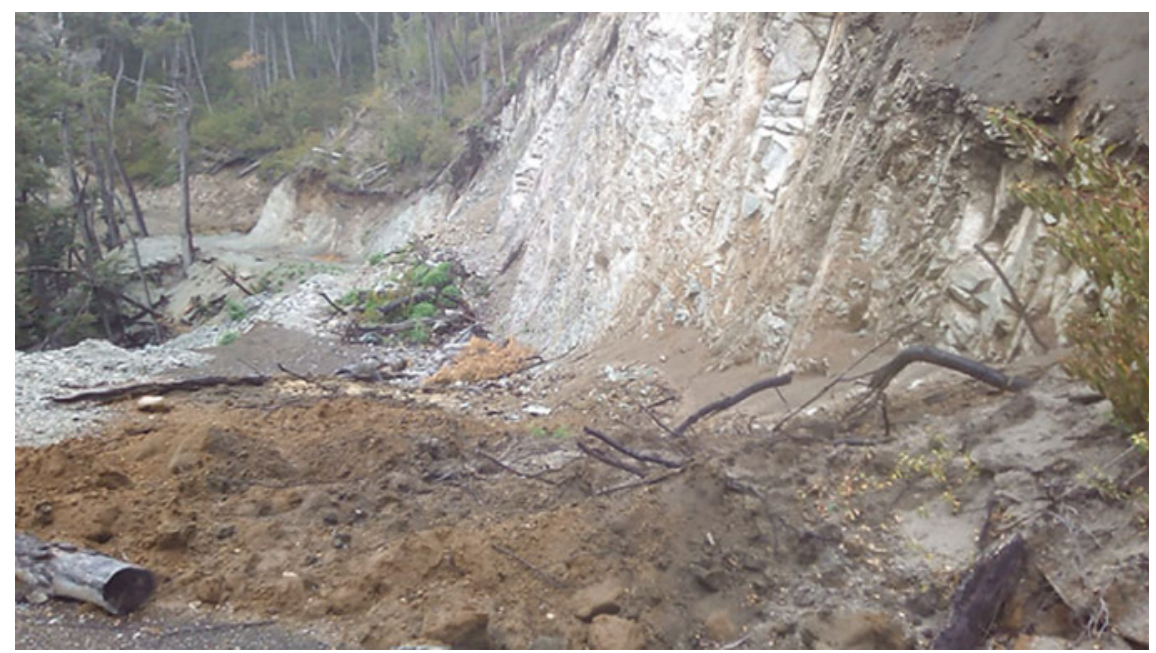

Fig. 5 Opening up a road in the area called Pichunco, Villa La Angostura, province of Neuquén, Argentina, 2019. Source Photograph taken by Gabriel Stecher 


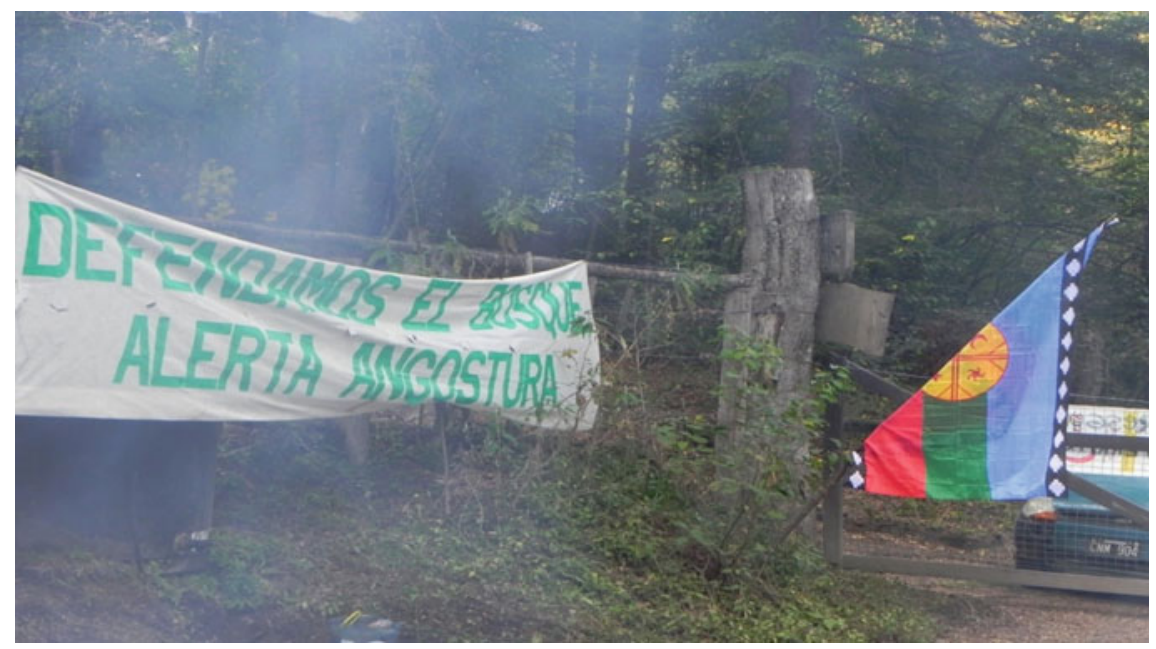

Fig. 6 Entrance to the "environmental protection" area, Villa La Angostura, province of Neuquén, Argentina. Source Photograph taken by Gabriel Stecher

\section{Río Negro: Conservation and Sustainable Use of Native Forests}

As it was previously mentioned, there are 478,900 ha of native forests managed pursuant to the provisions of Río Negro Provincial Law No. 4,552, through which Río Negro province abided by the terms established by the Forest Law. It addresses a surface located in the mountain strip to the Southwest of the province (Department of San Carlos de Bariloche). We also mentioned that according to the first OTBN conducted in the jurisdiction in 2010, 38\% of the native forest area was included in Category I (red), 53\% in Category II (yellow) and the remaining $9 \%$ in Category III (green) (Fig. 7).

This first zoning process - developed only by the province-was reviewed in February 2015, i.e., long after the two years established by provincial law to conduct the review had gone by, and even today such review has not been submitted for approval to the provincial Parliament. The review process, which started in February 2011, was conducted by the Enforcement Authority, the Provincial Enforcement Unit for the Protection of Native Forests (UEP-PBN), through the Advisory Council in the Andean Area, created by the Unit. ${ }^{8}$ The role of this Council was to advise the Forest Division of the provincial Ministry of Agriculture, Livestock and Fisheries (MAGyP) and the provincial Secretariat of Environment

\footnotetext{
${ }^{8}$ For a detailed analysis of the Advisory Council's actions on the social management of the territory, and in particular, an analysis of the actors (their interests, positions, demands) involved in the participatory process led by this consultative-participatory body, see Namiot (2018).
} 


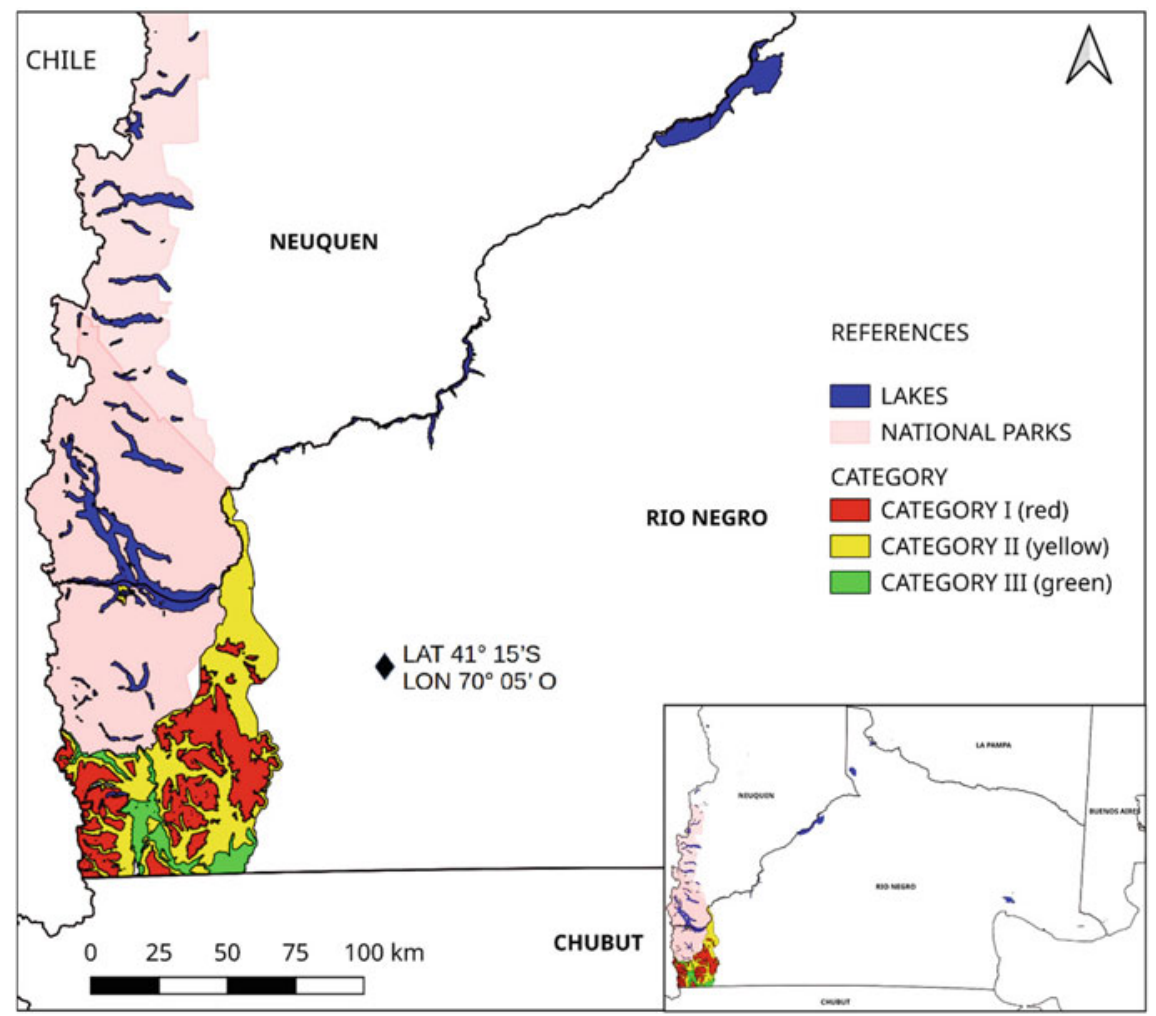

Fig. 7 Territorial Planning of Native Forests (OTBN), province of Río Negro, Argentina. Source Map made by the authors, based on data from the National Monitoring System of Native Forests of the Argentine Republic. Free software QGIS 3.12 Bucurestti

and Sustainable Development (SAyDS) on matters related to the effective implementation of Provincial Law 4,552 in the territory, although its judgment was not binding. The Council consists of public and private institutions interested in the conservation of native forests, and it focused on seven core areas: governmental; academic and research; intermediate non-governmental organizations; professional associations; indigenous peoples; primary producers and rural dwellers; forest service providers and related industries. Among the indigenous peoples, different Mapuche communities participated in that instance: Huaytekas, Tacul, Huenchupan, Huenuleo, Quijada, Ranquehue, Tripay Antu, Follil, Rayen Mapu, Nirihuau (Namiot 2018).

The rezoning process under the OTBN was based on the revision of the criteria used in 2010 with proposals to modify or to include a new one. In this sense, the first OTBN did not consider all the sustainability criteria set forth in the law: the one related to biological aspects had a greater significance, while those related to the value indigenous communities attach to native forests was not taken into account 
(Ministry of Environment and Sustainable Development of Argentina-MAyDS 2017). However, the 2015 zoning process did not include some essential criteria either, such as the value and the use given by these communities to the forested areas for the (concrete and symbolic) purpose of social (re)production of their lives. Rather, its definition mainly focused again on the biological aspects and, at most, the productive uses of those areas (UEP-PBN 2013). The main changes between the territorial zoning of native forests drafted in 2010 and the one drafted five years later were the reduction of the yellow and green categories (by 32\% and 16\%, respectively), in particular, and of the native forests surface (by 13\%), in general (Namiot 2018).

The delay in the provincial Legislature's approval of the 2015 review resulted in a formal warning issued by the Federal Council for the Environment (COFEMA) to the governor. It also occurred simultaneously with the non-implementation of the budget allocated for the enforcement of this law. Although the province received the corresponding annual compensation through the National Fund for the Enrichment and Conservation of Native Forests, the government only implemented the percentage allocated to forest institutional strengthening, retaining the funds that had to be sent to the producers. Hence, over one hundred plans (mainly, sustainable management plans) presented by forested land owners between 2010 and 2015 for the harnessing of the forest resources (both its timber and non-timber resources) were left without the necessary approval and financing to be implemented (Río Negro Newspaper 2018).

In line with the low participation of indigenous and peasant communities among the landowners who submitted plans for 2015 (1.3\% of the total, at a national level) (Ministry of Environment and Sustainable Development of Argentina-MAyDS 2017), few communities - among the seven involved in the participatory processsubmitted a management plan. ${ }^{9}$ One of them was Las Huaytekas, settled in the rural areas of El Foyel and Los Repollos (about $70 \mathrm{~km}$ from the city of San Carlos de Bariloche and $40 \mathrm{~km}$ from the town of El Bolsón, in the Department of Bariloche). Its territory, rich in forest species, has led both to the search for its conservationthrough National Law No. 26,331 as well as through previous legislation-and to its exploitation by capitals focused on industrial logging.

Therefore, on the one hand, this community's territory is now almost entirely included within the limits of Cipresal de las Guaitecas Protected Natural Area (ANPCG). The area (around 4,000 ha) was created by Provincial Law No. 4,047 in 2005, to ensure the conservation of the relict species of Guaitecas cypress, mountain cypress, and larch (all of them, endangered or vulnerable species) and of the biological diversity and the ecological and natural evolutionary processes that create and/or affect this relict. The cypress area hosts activities related to the

\footnotetext{
${ }^{9}$ Technical difficulties faced when completing the required administrative procedures might explain the low proportion of plans implemented by indigenous communities. The "Forest Law" foresees that a part of the $30 \%$ of the fund granted to the provinces is used for technical and financial assistance to small producers (indigenous and peasants communities). However, it is unknown to what extent this was actually implemented (Aguiar et al. 2018).
} 
material subsistence of the community (obtaining water, grazing animals, collecting mushrooms and medicinal plants). It also includes their rewe (spiritual and ceremonial site), where the kamaruko (a Mapuche ceremony) is performed. Different judicial decisions have recognized the significance of the cypress area for the reproduction of their traditional practices and identity as a people, and the community's rights over that space (Amico et al. 2014). Although the Protected Natural Area was created without prior consultation or participation and, even more so, with opposition from the community (Las Huaytekas 2009), an agreement was reached later on with the Council of Ecology and Environment (CODEMA) to implement a management plan for the cypress area. Eight years after the start of its elaboration, this plan has not been approved yet.

On the other hand, private and State capitals claimed to be interested in implementing afforestation plans, to justify the acquisition of fractions of fiscal lands - often through irregular transfers- that overlapped with the community's traditional territory. Incidentally, forestation initiatives with fast-growing exotic conifers (whether it implied clearing the native forests or not) have been promoted by the national and provincial States since the 1970s and led by private and mixed capitals (with State participation). This activity has not been highly developed: the forested area in Río Negro amounts to barely $11 \%$ of the forested area in the northwestern region of Patagonia (around 11,860 ha), a much lower figure than in Neuquén province (National Service of Agri-Food Health and Quality - SENASA 2017). However, afforestation has been pointed out by Mapuche communities and organizations as a tool used by those capitals for the appropriation of their territory (Consejo Asesor Indígena-CAI 2011). ${ }^{10}$ Thus, on the one hand, the indigenous groups that organize their production based on subsistence work find it difficult to access the necessary transportation guides for the use and/or commercialization of forest products (firewood and wood), since their occupied and/or claimed territories are not effectively recognized. On the other hand, companies focused on wood production extract these resources for their use and benefit, or they change their initial purpose of wood production and become tourism and real estate enterprises,

\footnotetext{
${ }^{10}$ In this sense, the afforestation processes carried out by the Forestry Company of Río Negro (EMFORSA) (of mixed capitals, and focused on the afforestation, industrialization, and commercialization of forest raw materials) are paradigmatic. These capitals have been involved not only in land transfers to private hands, but also in an irregular transfer. In 1999, around 289 ha of fiscal land were transferred to EMFORSA. Then, the State contributed its own land as capital. One year later, when the company was in a financial deficit situation, that parcel of land was sold - at its assessed value - to the former chairperson of the company between 1998 and 2012, who owned an adjacent parcel of land. He gained ownership only in 2001, after starting an eviction trial against an occupier of the fiscal land. That same year, he transferred the lands to Hidden Lake (a British corporation that owns 11,284 ha in the Department of Bariloche) (Iñigo Carrera 2020). Such land is part of the Lof Palma-Villablanca territory, a member of Las Huaytekas community.
} 
within the framework of an ongoing increase of land prices since the late 1980swith even greater intensity during the $2000 \mathrm{~s}$ - particularly in tourist fractions of land, on the river or lake shore. ${ }^{11}$

In this sense, the defense of the occupied and/or claimed territory, and the access and control of its resources - including, among others, the possibility of firewood extraction, a typical activity among indigenous and non-indigenous small producers - are the cornerstones on which Las Huaytekas community has based its main political actions for the last eight years (land recoveries, installing a gate to prevent entry to the territory, festivals, peaceful occupation of provincially-managed buildings, celebration of kamarucos, legal appeals). These actions have gained visibility on both the provincial and the national levels. ${ }^{12}$

\section{Final Remarks}

Throughout our work we presented general principles set forth by National Law No. 26,331 on "Minimum Standards for the Environmental Protection of Native Forests" (known as the "Forest Law") and the respective laws that Neuquén and Río Negro provinces abided by. We then analyzed the territorialities configured by the State, the capitals and small producers in relation to the territorial planning of native forests - in particular - and the conservation of nature - in general - as well as the territorial conflicts sparked by these different logics, both in the departments of Los Lagos (Neuquén) and Bariloche (Río Negro).

These conflicts stem from the development of different public and private ventures on the lands and territories occupied by the small producers who belong to - or identify themselves as belonging to - the indigenous peoples, as well as those with criollo origin. Thus, public policy regarding the definition of territorial planning of native forests is pressed between the protection and conservation of natural resources, on the one hand, and the valuation of industrial capitals applied to different productive activities, including tourism and forestry, on the other. It is a tension that is contained in it but also transcends it, and that emerges in the form of the above-mentioned conflicts. In other words, in analyzing the implications of this public policy in relation to the territorialities configured by the different social

\footnotetext{
${ }^{11}$ One of the reasons given by the then Deputy Secretary of Forest Resources of the Ministry of Agriculture, Livestock and Fisheries of the province - when submitting his resignation in 2014for the delay in submitting the new OTBN, established for 2012, was the dispute about the zoning classification as Category III (green) or Category II (yellow) of the land parcels included in the Cerro Perito Moreno Comprehensive Development Project (Agencia Digital de Noticias 2014). This project is a tourism and real estate development one, around $25 \mathrm{~km}$ away from El Bolsón, located within different nature conservation areas, which entailed the development of a ski center and a tourist village at the base of the hill (Iñigo Carrera 2019).

${ }^{12}$ This is common to other communities throughout Patagonia (Briones and Ramos 2020; Schiaffini 2019; Tozzini 2014; among others).
} 
subjects, we must reconsider the question about the relationship between nature conservation and the (re)creation of the necessary conditions for capital accumulation, through the dispossession of land and natural resources, the exclusion of local populations, and the promotion of nature-based tourism, among other mechanisms. Although at first sight it may seem contradictory, the link between these aspects is not necessarily obvious or immediately perceived.

\section{References}

Agencia Digital de Noticias (2014, September 1st) Renunció Javier Grosfeld a la Subsecretaría de Recursos Forestales. Last access: 9 Oct 9 2020. https://adnrionegro.com.ar/2014/09/renunciojavier-grosfeld-a-la-subsecretaria-de-recursos-forestales/

Aguiar S, Mastrangelo M, García Collazo M, Camba Sans G, Mosso C, Ciuffoli L, Schmidt M, Vallejos M, Langbehn L, Cáceres D, Merlinsky G, Paruelo J, Seghezzo L, Staiano L, Texeira M, Volante J, Verón S (2018) ¿Cuál es la situación de la Ley de Bosques en la Región Chaqueña a diez años de su sanción? Revisar su pasado para discutir su futuro. Ecología Austral 28:400-417

Amico G, Briones C, López Alaniz P, Nahuelquir F, Ñancunao M, Paritsis J, Puntieri J, Ruiz C (2014) Informe final. Elaboración e implementación de un plan de manejo preliminar del Área Natural Protegida Cipresal de las Guaitecas (ANPCG). San Carlos de Bariloche

Arach A, Stecher G (2019) Proceso de revisión del OTBN en el sur de Neuquén. Experiencias de participación de los actores socioterritoriales. IV Jornadas Forestales de Patagonia Sur. IV Congreso Internacional Agroforestal Patagónico. Universidad Nacional de Tierra del Fuego, Ushuaia

Blanco G, Arias F (2018) Las comunidades indígenas en Neuquén y la política de tierras en el largo plazo (fines del siglo XIX - fines del siglo XX). In: Blanco G (ed) La tierra pública en la Patagonia. Normas, usos, actores sociales y tramas relacionales. Prohistoria, Rosario, pp 227 257

Briones C, Ramos A (2020) Los porqués del "de acá nos van a sacar muertos". Procesos de recuperación de tierras en la Patagonia Norte. Intersticios de la política y la cultura. Intervenciones latinoamericanas 9(17):9-43

Consejo Asesor Indígena (CAI) (2011, May 6th) La forestación como instrumento de apropiación del territorio en Cuesta del Ternero. Last access: 15 Oct 2020. http://argentina.indymedia.org/ news/2011/05/778965.php

Delrio W, Lenton D, Musante M, Nagy M, Papazian A, Pérez P (2010) Discussing indigenous genocide in Argentine: past, present, and consequences of Argentinean state policies toward native peoples. Genocide Stud Prev Int J 5(2):138-159

Encabo M, Sánchez S, Torre G, Paz Barreto D, Andrés J, Mastrocola Y, Vázquez V, Cánepa L (2016) Uso responsable de biodiversidad. Revisando el modelo recreación y turismo en conservación. Anuario de Estudios en Turismo. Investigación y Extensión 16(XI):8-20

García A, Valverde S (2007) Políticas estatales y procesos de etnogénesis en el caso de poblaciones mapuche de Villa La Angostura, provincia de Neuquén, Argentina. Cuadernos De Antropología Social 25:111-132

Giarracca N (2006) Territorios en disputa: los bienes naturales en el centro de la escena. Realidad Económica 217:51-68

Iñigo Carrera V (2019) Relaciones capitalistas y conflictos territoriales: una aproximación a su emergencia y desarrollo en la cordillera rionegrina. In: Kropff L, Pérez P, Cañuqueo L, Wallace $\mathbf{J}$ (eds) La tierra de los otros. La dimensión territorial del genocidio indígena en Río Negro y sus efectos en el presente. Universidad Nacional de Río Negro, Viedma, pp 185-215 
Iñigo Carrera V (2020) Las formas del despojo en la cordillera rionegrina: a propósito de las trayectorias de dos empresas forestales, Pilquen. Sección Ciencias Sociales 23(2):14-28. Last access: 9 Oct 2020. http://revele.uncoma.edu.ar/htdoc/revele/index.php/Sociales/article/view/ 2630

Las Huaytekas (2009, September 23rd) Comunicado para la prensa. Last access: 9 Oct 2020. https://www.barilochense.com/bariloche-social/pueblomapuche/rio-negro-comunidadmapuche-las-huaytekas-recupera-territorio

Merlinsky G (2013) Introducción. La cuestión ambiental en la agenda pública. In: Merlinsky G (Compilator) Cartografías del conflicto ambiental en Argentina. CICCUS-CLACSO, Buenos Aires, pp 19-60

Ministerio de Ambiente y Desarrollo Sustentable de la Nación (MAyDS) (2017) Ley N 26.331 de Presupuestos Mínimos de Protección Ambiental de los Bosques Nativos. Informe de estado de implementación 2010-2016. Last access: 9 Oct 2020. https://www.google.com.ar/url\%3Fsa\% 3Dt\%26rct\%3Dj\%26q\%3D\%26esrc\%3Ds\%26source\%3Dweb\%26cd\%3D1\%26ved\% 3D2ahUKEwj6v4zksdHnAhV_E7kGHTWyB-cQFjAAegQIAxAB\%26url\%3D https://www. argentina.gob.ar/sites/default/files/informe_de_implementacion_2010_-_2016.pdf\%26usg\% 3DAOvVaw1Ojs4KpTebNhfGGltDup9G

Namiot G (2018) Percepciones, intereses y relación de fuerzas en el Ordenamiento Territorial de los Bosques Nativos. Estudio de caso: Consejo Consultivo en El Bolsón, Provincia de Río Negro. Unpublished master thesis, Universidad Nacional del Comahue

Río Negro Newspaper (2018, August 5th) Río Negro incumple la ley de Bosque Nativo y retiene fondos. Last access: 9 Oct 2020. https://www.rionegro.com.ar/rio-negro-incumple-la-ley-debosque-nativo-y-retiene-fondos-BD5511355/

Schiaffini H (2019) Conflictividad rural, estructura social y etnicidad en Chubut. Las "recuperaciones territoriales mapuche" en perspectiva social e histórica. Entramados y perspectivas $9(9): 3-32$

Schmidt M (2015) Política ambiental, avance de la frontera agropecuaria y deforestación en Argentina: el caso de la ley "De Bosques." GeoPantanal 18:121-139

Seoane J (2006) Movimientos sociales y recursos naturales en América Latina: resistencias al neoliberalismo, configuración de alternativas. Sociedade e Estado 21(1):85-107

Servicio Nacional de Sanidad y Calidad Agroalimentaria (SENASA) (2017) Anuario estadístico 2016. General Roca. Last access: 9 Oct 2020. http://www.senasa.gob.ar/institucional/centrosregionales/centros-regionales/patagonia-norte

Stecher G (2013) Ley de Bosques. Su aplicación en territorios de comunidades campesinas e indígenas en la Provincia de Neuquén. Nuevos modos de exclusión. VII Jornadas Santiago Wallace de Investigación en Antropología Social. Universidad de Buenos Aires, Buenos Aires

Stecher G, Arach A, Nahuel F, Lonkon L (2018) Informe apertura camino Lote 9 sector Pichunco. Universidad de Buenos Aires, Buenos Aires

Tamagno L (2014) Políticas indigenistas hoy. Un nuevo «parto de la antropología». Etnicidad y clase. In: Trinchero H, Campos Muñoz L, Valverde S (Coordinators) Pueblos indígenas, conformación de los estados nacionales y fronteras. Tensiones y paradojas de los procesos de transición contemporáneos en América Latina. Editorial de la Facultad de Filosofía y Letras, Buenos Aires, pp 9-35

Tozzini A (2014) Pudiendo ser mapuche. Reclamos territoriales, procesos identitarios y Estado en Lago Puelo, provincia de Chubut. Universidad Nacional de Río Negro, Viedma

Trinchero HH (2006) The genocide of indigenous people in the formation of the Argentine nation-state. J Genocide Res 8(2):121-135

Trpin V, Rodríguez MD (2019) Transformaciones territoriales y desigualdades en el norte de la Patagonia: extractivismo y conflictos en áreas agrarias y turísticas. Albuquerque. Revista de Historia 10(20):50-66

Unidad Ejecutora Provincial de Protección de Bosques Nativos (UEP-PBN) (2013) Criterios de zonificación de Ley de Protección de Bosques Nativos 4.552. Consejo Consultivo de Bosques Nativos. Resumen de acuerdos y desacuerdos. San Carlos de Bariloche 
Valtriani A, Stecher G (2019) Aspectos cualitativos y cuantitativos. Comparativos de su aplicación en dos provincias patagónicas. IV Jornadas Forestales de Patagonia Sur - IV Congreso Internacional Agroforestal Patagónico. Universidad Nacional de Tierra del Fuego, Ushuaia

Valverde S, Maragliano G, Impemba M (2015) Expansionismo turístico, poblaciones indígenas Mapuche y territorios en conflicto en Neuquén, Argentina. Pasos. Revista de Turismo y Patrimonio Cultural 13(2):395-410 